\title{
Peningkatan Pengetahuan dan Ketrampilan Ibu Menyusui Dalam Pemberian Terapy Komplementer Massage Endorphin dan Pijat Laktasi di Debong Lor
}

\author{
Evi Zulfiana*, Ulfatul Latifah, Mutiarawati, Nora Rahmanindar \\ Politeknik Harapan Bersama Tegal, Tegal, Indonesia \\ Email: evi.zulfiana33@gmail.com
}

\begin{abstract}
Abstrak-Menyusui merupakan proses yang alamiah yang tidak mudah di lakukan. Cakupan ASI eksklusif tidak lepas dari masalah yang terjadi dalam proses menyusui diantaranya adanya kepercayaan yang salah bahwa ASI keluar sedikit atau ASI kurang mencukupi kebutuhan bayi. Keadaan ini disebabkan oleh beberapa faktor antara lain makanan dan minuman yang dikonsumsi oleh ibu, kondisi psikologis atau emosi ibu, bentuk payudara yang tidak normal. Metode baru yang diperkenalkan untuk mencegah dan mengatasi permasalahan ini diantaranya adalah massage endorphine dan pijat Laktasi tehnik pemijatan yang dilakukan pada daerah kepala atau leher, punggung, tulang belakang, dan payudara yang bertujuan untuk merangsang hormone prolaktin dan oksitosin. Tujuan pengabdian ini untuk meningkatkan pengetahuan dan ketrampilan ibu menyusui dalam melakukan massage endorphine dan pijat laktasi. Metode yang dilakukan adalah dengan memberikan pelatihan diawali dengan pemebrian materi cara menyusui yang benar. Hasil pelatihan yang sudah sudah diberikan pada ibu menyusui yang mengikuti posyandu sudah mengetahui dan trampil dalam mempraktekkan massage endorphine dan pijat laktasi.
\end{abstract}

Kata Kunci: Ketrampilan Ibu Menyusui; Massage Endorphin; Pijat Laktasi

\begin{abstract}
Breastfeeding is a natural process that is not easy to do. Exclusive breastfeeding coverage can not be separated from the problems that occur in the breastfeeding process including the false belief that breast milk comes out a little or breast milk is insufficient for the baby. This condition is caused by several factors including food and drinks consumed by the mother, the psychological or emotional condition of the mother, abnormal breast shape. New methods introduced to prevent and overcome this problem include endorphin massage and Lactation massage massage massage technique performed on the head or neck, back, spine, and breast areas that aim to stimulate the hormone prolactin and oxytocin. The purpose of this devotion is to increase the knowledge and skills of nursing mothers in doing endorphin massage and lactation massage. The method is to provide training starting with the material of the correct way of breastfeeding. The results of training that has been given to breastfeeding mothers who follow posyandu already know and skill in practicing endorphine massage and lactation massage.
\end{abstract}

Keywords: Breastfeeding Skills; Endorphin Massage; Lactation Massage

\section{PENDAHULUAN}

Menyusui merupakan proses yang alamiah yang tidak mudah di lakukan. Cakupan ASI eksklusif tidak lepas dari masalah yang terjadi dalam proses menyusui diantaranya adanya kepercayaan yang salah bahwa ASI keluar sedikit atau ASI kurang mencukupi kebutuhan bayi. Keadaan ini disebabkan oleh beberapa faktor antara lain makanan dan minuman yang dikonsumsi oleh ibu, kondisi psikologis atau emosi ibu, bentuk payudara yang tidak normal sehingga tidak dapat berperan dalam proses menyusui, isapan bayi (reflex isap/kekuatan mengisap, lama mengisap, dan keseringan mengisap) juga dapat mempengaruhi produksi ASI (Permen RI, 2012). Indonesia sendiri telah mengupayakan untuk meningkatkan cakupakan ASI diantaranya program IMD (Inisiasi Menyusui Dini) dan perawatan payudara pada prenatal dan postnatal yang bertujuan untuk meningkatkan produksi ASI serta mencegah putting susu lecet (Marmi S, 2012).

Metode baru yang diperkenalkan untuk mencegah dan mengatasi permasalahan ini diantaranya adalah pijat Laktasi. Pijat laktasi adalah tehnik pemijatan yang dilakukan pada daerah kepala atau leher, punggung, tulang belakang, dan payudara yang bertujuan untuk merangsang hormone prolaktin dan oksitosin. Hormon yang berperan dalam produksi ASI adalah hormone prolaktin dan oksitosin saat terjadi stimulasi sel-sel alveoli pada kelenjar payudara berkontraksi, dengan adanya kontraksi menyebabkan air susu keluar dan mengalir kedalam saluran kecil payudara sehingga keluar tetesan susu dari putting dan masuk kedalam mulut bayi yang disebut dengan let down reflex (Sriyati, 2015).

Menurut penelitian Nurfaizah tentang pengaruh endorphin massage terhadap pengeluaran ASI pada ibu postpartum tahun 2020 dengan hasil Ibu post partum memiliki produksi ASI lancar setelah dilakukan endorphin massage lebih banyak dibandingkan dengan yang tidak dilakukan endorphin massage serta terdapat pengaruh endorphine message terhadap produksi ASI (Nurfaizah, 2020).

Berbagai penelitian yang telah dilakukan di Indonesia untuk memperlancar produksi ASI diantaranya adalah metode Pijat Oksitosin, Teknik Marmet, Kompres Hangat, Massage Rolling (punggung), massage Endorphin, Breast Care, tetapi karena keterbatasan informasi di layanan kesehatan tentang prosedur pelaksanaan maka metode-metode ini hanya dikenal saja tetapi jarang diberikan oleh tenaga kesehatan sebagai care giver kepada pasien (Istiqomah, 2015). 
Di Debong Lor masih banyak ibu post partum yang mengalami permasalahan produksi asi Untuk itu kami tertarik melakukan pengabdian kepada masyarakat di posyandu debong lor kota tegal.

\section{METODE PELAKSANAAN}

Metode pelaksanaan pengabdian dilakukan dengan memberikan pelatihan kesehatan terkait massage endorphin dan pijat laktasi di posyandu debong lor yang di dampingi oleh bidan dan kader serta melibatkan mahasiswa dalam kegiatan Pengabdian Kepada Masyarakat, sebelum melakukan pelatihan diisi dengan sosialisasi tentang cara menyyusui yang benar.

\section{a. Khalayak sasaran}

Sasaran utama dalam kegiatan pengabdian pada masyarakat ini adalah ibu menyusui yang mengikuti posyandu di debong lor.

\section{b. Kerangka pemecahan masalah}

Kegiatan Pengabdian Masyarakat yang dilaksanakan oleh Dosen dengan jumlah peserta 16 peserta yang terbagi dalam tiga kelas ibu hamil di Debong Lor melalui pelatihan kesehatan

\section{HASIL DAN PEMBAHASAN}

Hasil kegiatan pengabdian masyarakat yang dilaksanakan pada tanggal 26 November 2021 dihadiri 16 ibu menyusui diawali dengan sosialialisasi tentang cara menyusui yang benar setelah itu

Tabel 1. Hasil pelatihan I

\begin{tabular}{ccccc}
\hline Jumlah Ibu & \multicolumn{2}{c}{ Pengetahuan } & \multicolumn{2}{c}{ Ketrampilan } \\
Menyusui & Baik & Kurang & Baik & Kurang \\
\hline 16 & 5 & 11 & 3 & 13 \\
jumlah & 5 & 11 & 3 & 13 \\
\hline
\end{tabular}

Hasil pelatihan I yang dilakukan sebelum memberikan pelatihan adalah dengan memberikan pengetahuan kepada ibu tentang cara menyusui yang benar dengan total 16 ibu menyusui yang berpengetahuan baik sejumlah 5 orang dan yang kurang 11 orang, dilanjut pelatihan ketrampilan massage endorphin dan pijat oksitosin dari total 16 ibu menyusui 3 orang yang ketrampilannya baik, 13 orang masih kurang.

Tabel 2. Hasil pelatihan 2

\begin{tabular}{ccccc}
\hline \multirow{2}{*}{$\begin{array}{c}\text { Jumlah Ibu } \\
\text { Hamil }\end{array}$} & \multicolumn{2}{c}{$\begin{array}{c}\text { Pengetahuan Kesiapan } \\
\text { mental ibu hamil }\end{array}$} & \multicolumn{2}{c}{ Pengetahuan Covid } \\
& Benar & Salah & Benar & Salah \\
\hline 16 & 16 & - & 16 & - \\
Jumlah & 16 & - & 16 & - \\
\hline
\end{tabular}

Hasil pelatihan II yang dilakukan sebelum memberikan pelatihan adalah dengan memberikan pengetahuan kepada ibu tentang cara menyusui yang benar dengan total 16 ibu menyusui yang berpengetahuan baik sejumlah 16 orang dilanjut pelatihan ketrampilan massage endorphin dan pijat oksitosin dari total $16 \mathrm{ibu}$ menyusui 16 orang yang ketrampilannya baik.

Dari hasil pelatihan pertama masih ada ibu menyusui yang berpengetahuan kurang sejumlah 11 orang, sedangkan ketrampilan yang masih kurang 13 ibu menyusui, sedangkan di pelatihan yang ke dua semua ibu menyusui sudah baik dalam hal pengetahuan dan ketrampilan. Menurut penelitian ridawati tentang pengaruh endorphin massage terhadap pengeluaran ASI pada ibu postpartum tahun 2020 dengan hasil Ibu post partum memiliki produksi ASI lancar setelah dilakukan endorphin massage lebih banyak dibandingkan dengan yang tidak dilakukan endorphin massage serta terdapat pengaruh endorphine message terhadap produksi ASI.

\section{KESIMPULAN}

Kegiatan pengabdian kepada masyarakat dengan tema "Peningkatan Pengetahuan Dan Ketrampilan Ibu Menyusui Dalam Pemberian Terapy Komplementer Massage Endorphin Dan Pijat Laktasi Di Debong Lor" dapat diambil kesimpulan sebagai berikut: peningkatan pengetahuan dan ketrampilan ibu menyusui dalam memberikan massage endorphine dan pijat laktasi sudah sangat baik.

\section{DAFTAR PUSTAKA}

Peraturan Pemerintah Republik Indonesia Tahun (2012). Tentang pemberian ASI Ekslusif.jakarta 
Journal of Social Responsibility Projects by Higher Education Forum

Vol 2, No 2, November 2021, Page 91-93

ISSN 2723-1674 (Media Online)

Marmi, S. (2012). Panduan Lengkap Manajemen Laktasi. Yogyakarta : Pustaka Pelajar

Sriyati., dan Sari, Y. K. (2015). Pengaruh Pijat Punggung Terhadap Produksi ASI Ibu Post Partum Di Ruang Cempaka RSUD Ngudi Waluyo Wlingi. Jurnal Ners dan Kebidanan 2(2): 141-149

Nurfaizah, Nurhidayat, (2020) pengaruh endorphin massage terhadap produksi ASI ASI pada ibu postpartum 2(2) : 93-98

Istiqomah, Murwati Henik.(2015).Pengaruh Lama Dan Frekuensi Massage Teraphi Ibu Nifas Terhadap Depresi Postpartum. Jurnal Terpadu Ilmu Kesehatan,Volume 4, No 2,November2015, hlm 82-196 